Research Article

\title{
To evaluate and compare antidepressant activity of Rosa damascena in mice by using forced swimming test
}

\author{
Hemapriya Tirupathi*, Padmavathi Golla
}

Department of Pharmacology, Sri Padmavathi medical college for women, Tirupathi,

Andhrapradesh, India

Received: 25 June 2016

Accepted: 05 August 2016

*Correspondence to:

Dr. Hemapriya Tirupathi,

Email:

hemapriyatirupathi@gmail.com

Copyright: (C) the author(s), publisher and licensee Medip Academy. This is an openaccess article distributed under the terms of the Creative Commons Attribution NonCommercial License, which permits unrestricted noncommercial use, distribution, and reproduction in any medium, provided the original work is properly cited.

\begin{abstract}
Background: Rosa damascene mill L ( $R$. damascena) is an ornamental plant that has several therapeutic (such as sedative and hypnotic) effects. It also heals depression, grief, nervous stress and tension. In the present study we evaluated antidepressant-like effect of $R$. damascena using forced swimming test (FST). The forced swim test is a commonly used stressor test, where mice are forced to swim in specially constructed tanks for a particular period and looked for behavioural activation characterized by vigorous swimming and diving to search for alternate routes to escape. Animal health including human has been shown to be affected by the stressful events of the life inducing situation which alters cognition, learning memory and emotional responses, causing mental disorders like depression and anxiety and stress in mice.

Methods: The experiment was carried out with 24 healthy albino mice of either sex weighing about 25-30 gm. These were acclimatized to their environment for one week prior to experimentation. Two doses of aqueous extract (20 and 40 $\mathrm{mg} / \mathrm{kg}$ ) were injected intraperitoneally. After $30 \mathrm{~min}$ of injection, immobility and swimming times were measured and compared with control (negative control) and imipramine (positive control).

Results: In the present study $R$. damascena in the doses of $20 \mathrm{mg}$ and $40 \mathrm{mg} / \mathrm{kg}$ significantly decreased the immobility time compared to the control than standard, thereby proving that it has antidepresssant activity. The dose of $40 \mathrm{mg} / \mathrm{kg}$ body weight showed anti-depressant activity almost similar to the standard dug imipramine $(10 \mathrm{mg} / \mathrm{kg})$.

Conclusions: Antidepressant activity of $R$. damascena was studied by forced swimming test in mice in the doses of $20 \mathrm{mg} / \mathrm{kg}$ and $40 \mathrm{mg} / \mathrm{kg}$. This test shows that $R$. damascena significantly decreased the immobility time in mice. The results suggest that $R$. damascena has dose dependent antidepressant activity comparable with imipramine.
\end{abstract}

Keywords: Rosa damascena, Mice, Immobility time, Antidepressant like effect

\section{INTRODUCTION}

Rosa damascena mill L ( $R$. damascena), commonly known as Damask rose, is one of the most important species of Rosaceae family which is a well-known ornamental plant in the world that has been referred to as the king of flowers. ${ }^{1-3}$

The major cultivation areas of $R$. damascena in Iran are Kashan, Fars and Azerbaijan, among them Kashan is the most famous one. ${ }^{4}$ The most therapeutic effects of $R$. damascena in ancient medicine are treatment of abdominal and chest pain, strengthening the heart, treatment of menstrual bleeding and digestive problems and reduction of inflammation, especially of the neck.,
North American Indian tribes used a decoction of the root of $R$. damascena plant as a cough remedy to ease children's cough. ${ }^{7}$ This plant is also used as a gentle laxative. ${ }^{8}$ Rose oil heals depression, grief, nervous stress and tension. It helps in the reduction of thirst, old cough, special complaints of women, wound healing, and skin health. Vapour therapy of rose oil is helpful for some allergies, headaches, and migraine. ${ }^{8,9}$ Several components were isolated from flowers, petals and hips (seed-pot) of $R$. damascena including terpenes, glycosides, flavonoids and anthocyanins. This plant contains carboxylic acid, myrcene, vitamin $\mathrm{C}$, kaempferol and quarcetin. ${ }^{10-16}$

The antidepressant activity of $R$. damascena was also reported. $R$. damascena contains several components 
such as flavonoids and kaempefrol responsible for its antidepressant activity. Based on this evidence, in the present study antidepressant effects of aqueous extract of $R$. damascena was evaluated by forced swimming test (FST).

\section{METHODS}

\section{Plant material and preparation of extract of Rosa damascena}

Plants were collected from Nellore district, Andhra Pradesh, India. The plant was authenticated for its correct botanical identity by the chief botanist. The aqueous extract of plant was prepared as follows: 400 gms of the chopped, dried flowers of plant were extracted with $2 \mathrm{~L}$ of distilled water by the soxhlet apparatus. The solvent used for obtaining extract was evaporated by a rotator evaporator under reduced pressure at $50^{\circ} \mathrm{c}$. The final extracted material weighed $10 \mathrm{gm}$ that was prepared by dissolving final product in distilled water. ${ }^{17}$

\section{Animals}

Swiss albino mice weighing 25-30 grams of either sex were obtained from the central animal house of Narayana Medical College, Nellore.

They were housed in standard polypropylene cages with paddy husk as bedding and kept under controlled room temperature $\left(21-23^{\circ} \mathrm{C}\right.$; relative humidity $\left.60-70 \%\right)$ in a 12 $\mathrm{h}$ light-dark cycle. Animals were given a standard laboratory diet and water ad libitum. All experiments were performed between 09:00 AM and 3:00 PM in order to minimize the effect of circadian rhythms. Animals were acclimatized to laboratory conditions one week prior to initiation of experiments.

\section{Force swimming test}

Albino mice of either sex weighing from 25 to $30 \mathrm{~g}$ were used in this study. These were acclimatized to their environment for one week prior to experimentation. The animals were randomly distributed into four different groups. Each experimental group consisted of a 6 animals. Each group is caged separately after recording its body weight and the animals were marked with marker for identification. ${ }^{18}$

\section{Equipment}

Glass chamber, stop watch

\section{Experimental groups}

The experimental animals were weighed, and randomly divided into four groups, each group consisting of six animals $(n=6)$ were used.
Group I - Control group (saline) - $0.5 \mathrm{ml}$.

Group II - Standard group (Imipramine) $-10 \mathrm{mg} / \mathrm{kg}$.

Group III - Test group (aqueous extract of $R$. damascena) $-20 \mathrm{mg} / \mathrm{kg}$.

Group IV - Test group (aqueous extract of $R$. damascena) - $40 \mathrm{mg} / \mathrm{kg}$.

\section{Principle}

When an animal is forced to swim, it tries to escape by making rigorous movements. When it cannot escape from the glass chamber, the animal surrenders to the situation and floats making very little or no movements (immobility) in glass chamber. Thus forced swimminginduced immobility is considered as helplessness or a state of depression in animals. Antidepressant drugs reverse or reduce immobility period.

\section{Procedure}

Normal saline, Imipramine in the dose of $10 \mathrm{mg} / \mathrm{kg}$ (I.P) and $R$. damascena was administered intraperitoneally at different doses (20 and $40 \mathrm{mg} / \mathrm{kg}$, I.P) to mice of either sex. Forced swimming test was conducted after half an hour of drug administration. Mice were allowed individually to swim inside the glass chamber (25-12-25 $\mathrm{cm}$ ) containing water up to $15 \mathrm{~cm}$ height for $6 \mathrm{~min}$ at room temperature. After initial struggle to escape for 1-2 min the animal became immobile or had little movements to keep floating in the water. Total immobility period was measured during the $6 \mathrm{~min}$ in all groups. Later immobility period was compared in all groups. All the experimental procedures and protocols used in this study were carried out according to the guidelines of institutional animal ethical committee and ethical committee clearance was obtained from IAEC (Institutional Animal Ethics Committee).

\section{RESULTS}

The mean immobility time of control group was 179.33 \pm 4.5 . For imipramine it was 119.6 \pm 2.65 . Immobility time of $R$. damascena in the dose of $20 \mathrm{mg}$ and $40 \mathrm{mg}$ was $154 \pm 3.57$ and $131 \pm 3.7$ respectively. The mean immobility time was decreased significantly as given in Table 1 and Figure 1.

Table 1: Antidepressant activity of $R$. damascena using forced swimming test.

\begin{tabular}{|lll|}
\hline S.No. & Groups & $\begin{array}{l}\text { Mean immobility } \\
\text { time (sec) }\end{array}$ \\
\hline 1. & Control (normal saline) & $179.33 \pm 4.5$ \\
\hline 2. & $\begin{array}{l}\text { Standard } \\
\text { (imipramine } 10 \mathrm{mg} / \mathrm{kg})\end{array}$ & $1196 \pm 2.65 * * *$ \\
\hline 3. & $\begin{array}{l}\text { R. damascene } \\
(20 \mathrm{mg} / \mathrm{kg})\end{array}$ & $154 \pm 3.57 * * *$ \\
\hline 4. & $\begin{array}{l}\text { R. damascene } \\
(40 \mathrm{mg} / \mathrm{kg})\end{array}$ & $131 \pm 3.7 * * *$ \\
\hline$* * \mathrm{p}<0.001$ with R. damascena as compared to control
\end{tabular}




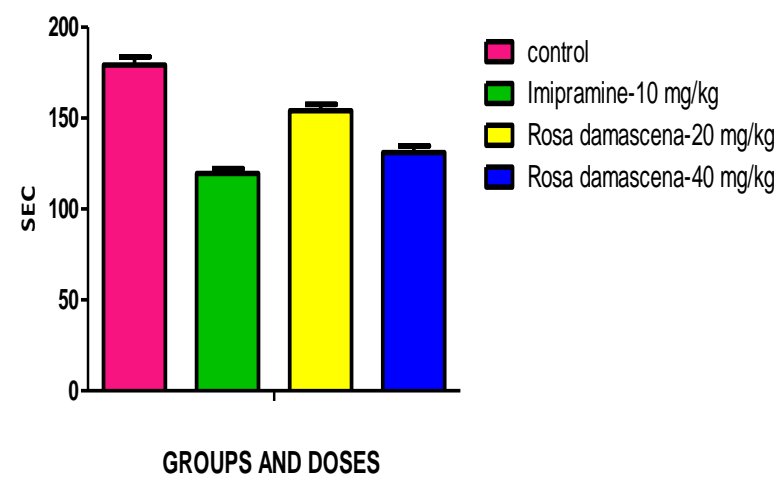

Figure 1: Mean time of immobility of $R$. damascene.

\section{DISCUSSION}

Porsolt's forced swimming test (Porsolt et al, 1977) is the animal model used in mice to check antidepressant properties. In this model immobility period was considered as a state of depression in mice. They proposed this behavioural model for the screening of new antidepressant compounds, concluded that the immobility time observed in the test reflected a state of lowered mood or hopelessness in animals, thus, this animal model is the most widely used tool for preclinical screening of putative antidepressant agents (Cryan et al, 2002 and 2005).

In the present study $R$. damascena in the doses of $20 \mathrm{mg}$ and $40 \mathrm{mg} / \mathrm{kg}$ significantly decreased the immobility time compared to the control than standard, thereby proving that it has antidepresssant activity. The dose of $40 \mathrm{mg} / \mathrm{kg}$ body wt showed anti-depressant activity almost similar to the standard dug imipramine $(10 \mathrm{mg} / \mathrm{kg})$.

Our study is supported by Dolati et al which showed antidepressant activity of $R$. damascena in mice using forced swimming test. ${ }^{17}$ The active principle involved in showing antidepressant activity is reuptake inhibition of monoamine neurotransmitters. Selvi et al showed antidepressant activity of $R$. damascena in rats using forced swimming test. They proposed that increase in serotonin levels and inhibition of reuptake of serotonin levels in brain might be the responsible for antidepressant activity. ${ }^{19}$ The antidepressant activity of $R$. damascena is probably by increase in monoamino-neurotransmitters in brain.

Funding: No funding sources

Conflict of interest: None declared

Ethical approval: The study was approved by the Institutional Ethics Committee

\section{REFERENCES}

1. Kaul VK, Singh V, Singh B. Damask rose and marigold: prospective industrial crops. J Med Aromat Plant Sci. 2000;22:313-8.
2. Nikbakh TA, Kafi M, Mirmasoudi M, Babalar M. Micropropagation of Damask rose (Rosa damascena Mill.) CVS Azaran and Ghamsar. International J of Agriculture and Biology. 2005;7(4):535-8.

3. Mahmood N, Piacente S, Pizza C, Burke A, Khan AL, Hay AJ. The anti-HIV activity and mechanisms of action of pure com-pounds isolated from Rosa damascena. Biochem Biophys Res Commun. 1996;229:73-9.

4. Nikbakht A, Kafi M. A Study on the Relationships between Iranian People and Damask Rose (Rosa damascena) and its Therapeutic and Healing Properties. Acta Hort (ISHS). 2008;790:251-4.

5. Wood G, Bache F. The Dispensatory of the United States of America, 4th ed. Philadelphia: Griggand Elliot; 1839: 80-86.

6. Buckle DR, Arch JRS, Boering NE, Foster KA, Taylor JF, Taylor SG, et al. Relaxation effect of potassium channel activators BRL 38227 and Pinacidil on guinea-pig and human airway smooth muscle, and blockade of their effects by Glibenclamide and BRL 31660. Pulm Pharmacol. 1993;6:77-86.

7. Libster M. Delmar's Integrative Herb Guide for Nurses. In: Delmar Thamson Learning. Albany; 2002: 360-370.

8. Zargari A. Medicinal Plants. 6th ed. Vol. 3. Tehran : Tehran University Publication; 1992: 281-284.

9. Momeni T, Shahrokhi N. Essential oils and their therapeutic actions. Vol. 6. Tehran, Iran. Tehran University Press; 1991: 101-108.

10. Green M. The Rose. Aromatic thymes. 1999;1:11-5.

11. Oka N, Ikegami A, Ohki M, Sakata K, Yagi A, Watanabe N. Citronellyl disaccharide glycoside as an aroma precursor from rose flowers. Phytochemistry. 1998;47:1527-9.

12. Knapp H, Straubinger M, Fornari S, Oka N, Watanabe N. (S)-3,7-Dimethyl-5-octene-1,7-diol and related oxygenated monoterpenoids from petals of Rosa damascena Mill. J Agri Food Chem. 1998;46:1966-70.

13. Shieber A, Mihalev K, Berardini N, Mollov P, Carle R. Flavonol glycosides from distilled petals of Rosa damascena Mill. Z Naturforsch C. 2005;60:379-84.

14. Kumar N, Singh B, Kaul VK. Flavonoids from Rosa damascena Mill. Nat Prod Commun. 2006;1:623-6.

15. Libster M. Delmar's Integrative Herb Guide for Nurses. In: Delmar Thamson Learning. Albany; 2002: 360-370.

16. Mahmood N, Piacente S, Pizza C, Burke A, Khan AL, Hay AJ. The anti-HIV activity and mechanisms of action of pure com-pounds isolated from Rosa damascena. Biochem Biophys Res Commun. 1996;229:73-9.

17. Dolati K, Rakhshandeh H, Naser-Shafei Md. Antidepressant-like effect of aqueous extract from Rosa damascene in mice Avicenna. Journal Phytomedicine Autum. 2011;1(2):91-7.

18. Gupta SK. Drug screening method, 1st edition. New delhi, Jaypee; 2004: 92-95. 
19. Thamarai selvi P, Kumar SM. Antidepressant activity of ethanolic extract of Rosa damascena. AsianJ.Res. Pharm. Sci. 2012;2(2):76-9.
Cite this article as: Tirupathi $\mathrm{H}$, Golla $\mathrm{P}$. To evaluate and compare antidepressant activity of Rosa

damascena in mice by using forced swimming test. Int J Basic Clin Pharmacol 2016;5:1949-52. 